\title{
MIĘDZY PATRIOTYZMEM I NACJONALIZMEM \\ NA TLE POPNACJONALIZMU W MUZYCE ROCKOWEJ
}

\author{
BETWEEN PATRIOTISM AND NATIONALISM: \\ POP-NATIONALISM IN ROCK MUSIC
}

\begin{abstract}
This article addresses issues which can be seen in the manifestation of ethno-nationalism in rock music. Concepts of nationalism and patriotism are illustrated by references to the literature on the subject. Polish national ideology is formed, for example, on a pragmatic concept of nationalism. A new direction in this work is an examination of pop-nationalism of rock music on the example of the Polish band "Horytnica."
\end{abstract}

Key words: patriotism; nationalism; pop-nationalism; rock music; "Horytnica"

\section{Streszczenie}

W artykule zajmuję się problematyką popnacjonalizmu przejawiającą się w muzyce rockowej. Ze względu na złożoność pojęć nacjonalizmu i patriotyzmu przytaczam interesujące nas tu opinie na ten temat $w$ literaturze przedmiotu. Pojęcie nacjonalizmu ustalam pragmatycznie na przykładzie deklaracji ideowych polskich organizacji narodowych. Novum w niniejszej pracy stanowi problem popnacjonalizmu w muzyce rockowej, przedstawiony na przykładzie twórczości zespołu „Horytnica”, odwołującej się do wspomnianych idei.

Stowa kluczowe: patriotyzm; nacjonalizm; popnacjonalizm; muzyka rockowa; "Horytnica”

MICHAL MAURYCY MAZURKIEWICZ Instytut Slawistyki PAN, Warszawa E-mail: echoe@interia.pl This work was supported by the author's own resources. No competing interests have been declared.

This is an Open Access article distributed under the terms of the Creative Commons Attribution 3.0 PL License (creativecommons.org/licenses/by/3.0/pl/), which permits redistribution, commercial and non-commercial, provided that the article is properly cited. (C) The Author(s) 2016.

Publisher: Institute of Slavic Studies, Polish Academy of Sciences [Wydawca: Instytut Slawistyki PAN] 
$\mathrm{P}$ ojęcie patriotyzmu starano się od wieków uściślić i jednoznacznie scharakteryzować. Jego fundamentem była miłość do ojczyzny, przy czym zarówno miłość, jak i ojczyznę pojmowano zgoła odmiennie, w zależności od kraju, narodu czy epoki. Przyjęto, że „patriotyzm to postawa łącząca przywiązanie i miłość do ojczyzny oraz solidarność z własnym narodem — z szacunkiem dla innych narodów i poszanowaniem ich suwerennych praw” („patriotyzm” - Encyklopedia PWN, b.d.). Podobnie zdefiniowano to pojęcie w internetowym słowniku języka polskiego: patriotyzm to „przywiązanie, miłość, najczęściej do ojczyzny, poczucie więzi społecznej oraz chęć, gotowość poświęcenia się dla własnego narodu, przy jednoczesnym poszanowaniu innych narodów i ich praw, kultur" („, patriotyzm” - Słownik SJP, b.d.). W Wielkim Słowniku Języka Polskiego zaś „patriotyzm to - postawa osoby, która kocha swoją ojczyznę, czuje się jej częścią, działa dla jej dobra i gotowa jest wiele dla niej poświęcić (, , patriotyzm” - WSJP, b.d.).

Próby rozróżnienia i znalezienia granicy, na podstawie której można byłoby dokonać podziału pomiędzy pojęciami patriotyzmu i nacjonalizmu intrygowały wielu badaczy. Przez wieki termin patriotyzm dotyczył przed wszystkim przywiązania do miejsca urodzenia okręgu, regionu czy kraju. W późniejszym czasie dopiero zaczął oznaczać lojalność wobec państwa terytorialnego, o czym pisał Anthony D. Smith (Smith, 2009, s. 181). Organizacje i ruchy które moglibyśmy posądzać o nacjonalizm, same niejednokrotnie definiują swe przekonania jako patriotyczne, co oczywiście jest lepiej odbierane przez społeczeństwo. Wynika to pośrednio z tego, żeby osiągnąć wspólnotę polityczną i aktywność obywateli własnego kraju, państwa wspierają postawy patriotyczne. Czynią to między innymi poprzez masowe i ujednolicone wychowanie publiczne i kult dawnego bohaterstwa (Smith, 2009: 180). Zdaniem Walkera Connora, który wiązał nacjonalizm z etnicznością, pojęcia patriotyzmu i nacjonalizmu nie powinny być mylone i utożsamiane. Według niego nacjonalizm odnosi się do emocjonalnego przywiązania do własnej grupy, a na przykładzie Stanów Zjednoczonych patriotyzmem jest lojalność obywateli wobec własnego państwa. Takie postrzeganie nie do końca przekonuje chociażby Michaela Billiga, który i w lojalności dostrzega elementy nacjonalizmu (Billig, 2008, s. 114).

Z kolei, jak pisze Reinhart Koselleck w książce Dzieje pojęć. Studia z semantyki i pragmatyki jezzyka społeczno-politycznego (Koselleck, 2009, ss. 235-258), „pojęcie 'patriota' chroni dzisiaj jego użytkownika przed postawieniem w negatywnym świetle jako nacjonalistę lub nawet szowinistę”. Zdaniem Kosellecka „właściwa kariera 'patrioty' rozpoczyna się we wczesnym XVIII wieku i staje się hastem wczesnego oświecenia politycznego we Francji, Anglii i Niemczech. 'Patriota' staje się 'ojcem' danego kraju. Ojczyzna staje się podmiotem, a ojcostwo jej atrybutem".

Zdaniem Kosellecka zmienia to semantykę polityczną, ponieważ pojawia się nowy podmiot pomiędzy władzą, a podwładnymi - osoba która kieruje się dobrem kraju. Osoba ta w pewien sposób wchodzi w obszary wcześniej zarezerwowane dla władcy. Koselleck zwraca uwage, że patriotyzm jest pierwszym pojęciem, które legitymizuje usamodzielnienie się obywatela i domaganie się uczestnictwa w sprawowaniu władzy w państwie. Autor ten przytacza również rozumienie patriotyzmu, utożsamianego z kosmopolityzmem. Podaje on przykład z okresu rewolucji francuskiej - w ten sposób legitymizowano wojnę domową i ekspansję własnej ideologii. Jak zauważa, rodzi to autentyczny patriotyzm innych ludów. W XIX wieku to właśnie narodowy patriotyzm był najważniejszy. Poświęcenie dla ojczyzny, umieranie za nią jest obecne od starożytności. „Gotowość umierania za 
ojczyznę została zrytualizowana. Stała się legitymującym testem prawdziwego patriotyzmu" (Koselleck, 2009, s. 249).

Już dwa wieki temu z patriotyzmem zaczyna być łączona gotowość poświęcenia życia dla ojczyzny i trwa do obecnych czasów. Jednak, także dzisiaj nie widać możliwości głębokiego rozróżnienia semantycznego pojęć patriotyzmu i nacjonalizmu i, jak twierdzi Koselleck, nie pomoże nam przekonywające moralnie przeciwstawienie dobrego i złego patriotyzmu. Również zastąpienie złego „patriotyzmu” godnym potępienia „nacjonalizmem” nie usuwa reguły semantycznej, zgodnie z którą dobry patriotyzm znajdujemy we własnym obozie, a zły w obozie przeciwnym. Należy się zgodzić ze zdaniem Kosellecka, że "patriotyzmu” podobnie jak „nacjonalizmu” nie można określić ontologicznie (Koselleck, 2009, s. 257). Jest to fakt wymagający szczególnej uwagi, gdyż zarówno nacjonalizm, jak i patriotyzm odnoszą się do tego samego obiektu (zjawiska): ojczyzny i miłości do ojczyzny (termin "ontologiczny" został użyty tu tak jak w filozofii, w której oznacza on naukę o istnieniu (por. Szymczak, 2006, ss. 16-21). Powstaje pytanie, skoro nie ontologicznie, jak inaczej można odróżnić pojęcie patriotyzmu od nacjonalizmu. Może da się je rozgraniczyć pragmatycznie? I czy takie rozgraniczenie byłoby bardziej widoczne i możliwe w kontekście kulturowym? Rozróżnienie bowiem patriotyzmu i nacjonalizmu przejawia się w wyksztatconym przez kulturę i edukację stosunku do ojczystej ziemi, jej języka i historii.

Miejscem, w którym młodzież spotyka się z pojęciem patriotyzmu, jest szkoła; młodzież może tu wykształcić w sobie postawy światopoglądowe. Nauczyciele chcący dowiedzieć się, jak według Ośrodka Rozwoju Edukacji powinni to uczynić, otrzymują wskazówki dość jednoznaczne. W bibliotece cyfrowej na stronach przywołanej instytucji dostępny jest kilkunastostronicowy opis najważniejszych zagadnień patriotyzmu oraz wskazówki dla nauczycieli pracujących w gimnazjum bądź liceum. Ośrodek Rozwoju Edukacji jest publiczną placówką doskonalenia nauczycieli o zasięgu ogólnokrajowym, prowadzoną przez Ministra Edukacji Narodowej. Powstał 1 stycznia 2010 roku w wyniku połączenia Centralnego Ośrodka Doskonalenia Nauczycieli i Centrum Metodycznego Pomocy Psychologiczno-Pedagogicznej. Ośrodek odsyła nauczycieli do lektury książek O patriotyzmie I. M. Bocheńskiego i Myśli nowoczesnego Polaka R. Dmowskiego. Wydaje się jednak, że w lekturach tych rozumienie patriotyzmu jest zbyt schematyczne. Przewodnik Ośrodka o patriotyzmie rozprawia się również z ignorowaniem patriotyzmu i jego symulowaniem takim jak kibicowanie podczas meczu piłkarskiego. Opracowanie dla nauczycieli kończy się cytatem za Stanisławem Brzozowskim: „Człowiek bez narodu jest duszą bez treści, obojętną, niebezpieczną i szkodliwą". Powyższy tekst powstał z silną tezą - patriotyzm jest bardzo ważnym elementem naszego życia. W tak przedstawionej tezie, co należy podkreślić, nie zauważa się jednak granicy między patriotyzmem i nacjonalizmem.

Podobnie interpretuje to pojęcie rock tożsamościowy. W tekstach utworów przedstawionych w dalszej części artykułu tak właśnie rozumie się patriotyzm - jako postawę najważniejszą w naszym życiu. Dla kogoś wyedukowanego w sposób, jaki proponuje Ośrodek Rozwoju Edukacji, teksty rocka tożsamościowego nie wydają się fanatyczne. Jak zauważa W. J. Burszta: „Uporczywie podkreślane przez myśl nacjonalistyczno-patriotyczną - poczucie obligacji, świadomości, iż jest się dłużnikiem wobec narodu, że naród wymaga ofiar, a wszyscy przynależący do narodowej wspólnoty winni się wspierać, stwarzając realną więź realnej pomocy między uczestnikami tego długu". Wydaje się, że właśnie w ten sposób patriotyzm postrzega Ośrodek Rozwoju Edukacji, jak i zespoły utożsamiające się z rockiem patriotycznym i tożsamościowym. 
Dzisiaj patriotą nie jest tylko ten, kto mieszka w kraju ojczystym. Jednak pierwotnie patriotyzm był podporządkowaniem się syna ojcu i wymogom wyłącznie ziemi ojczystej, a tym, co spajało rodaków, był „pater” - biologiczny i duchowy gwarant ciągłości rodzinnej. Jak twierdzi W. J. Burszta, „W naszym dzisiejszym rozumieniu patriotyzmu 'ojcem' jest ojczyzna (nie zawsze identyfikowana z państwem), w której żyją wszyscy ci, których określa się mianem rodaków" (Burszta, 2013a, s. 52). Naród postrzegany jest jako poszerzona rodzina przede wszystkim w kulturach patriarchalnych. Burszta, za White`em, zaznacza, że „patriotyzm jest szczególnie intensywny tam, gdzie rodziny pozostają patriarchalne w swej strukturze, a przeżywa kryzys lub wręcz poddawany jest w wątpliwość w indywidualistycznie nastawionych demokracjach liberalnych".

Zinstytucjonalizowanie patriotyzmu przez rządzących występuje w wielu miejscach na świecie. Społeczeństwo może wyrażać swe preferencje tylko w takim stopniu, w jakim wygodne jest to dla władz. Wartym uwagi przykładem może być Wietnam, gdzie władze państwowe dynamicznie zmieniają postrzeganie tego, kto jest głównym wrogiem narodu. Z jednej strony odchodzi się od ostrej retoryki wobec Stanów Zjednoczonych, z drugiej organizuje się „patriotyczne” manifestacje pod ambasadą chińską. Relację z protestów nadała państwowa telewizja. Demonstracje, które początkowo przebiegały w sposób pokojowy, przerodziły się w zamieszki. W prowincji Binh Duong zaatakowano fabryki należące - jak sądzono - do chińskich inwestorów. W rzeczywistości część tych zakładów jest tajwańska lub południowokoreańska (Kruczkowska, 2014; „Agresywne antychińskie protesty w Wietnamie. Spalono zagraniczne fabryki", 2014). Jak widać, łatwo doprowadzić do eskalacji protestów pod pretekstem haseł patriotycznych. Innym pokłosiem ostatnich wydarzeń w tym regionie jest oświadczenie ministra kultury Wietnamu, że trzeba będzie usunąć wszelkie posążki zwierząt inspirowane kulturami innymi niż wietnamska. Powstaje pytanie, czy jest to patriotyzm czy nacjonalizm.

Jak uważa W. J. Burszta, patriotyzm i nacjonalizm "niejako trzymane W ryzach w ramach demokracji liberalnych, (czym się one szczycą), uwalniane są bez skrępowania w jednej tylko dziedzinie kultury, a tą jest sport" (Burszta, 2013a, s. 53). Rywalizacja sportowa zastępuje sytuacje konfliktowe. Jest substytutem prawdziwych wojen, w których patriota przeistacza się $\mathrm{w}$ etnonacjonalistę.

Swoistym papierkiem lakmusowym pokazującym różnice między patriotyzmem i nacjonalizmem jest agresja „narodowa” utożsamiająca nas z "naszymi” walczącymi z "obcymi”. „Obcość przemienia się w końcu we wrogość, tym bardziej każda ze stron przeświadczona jest o swojej racji. Mają się na baczności, zamykają się W sobie. W sieci doświadczenia, które wychodzi od tego, co własne, i stara się utrzymać w tym, co wspólne, wbudowane są zabezpieczenia" (Waldenfels 2009: 4). Ugrupowania, które możemy uznać za nacjonalistyczne, postrzegają świat, w którym „Oni”, stają się „wrogiem”, z którym trzeba walczyć za wszelką cenę.

\section{POJĘCIE NACJONALIZMU}

Większość badaczy, jak chociażby Walker Connor czy Ernest Gellner, których przywołuje w swojej książce Anthony D. Smith, datuje powstanie pojęcia nacjonalizmu pod koniec XVIII wieku (Smith, 2009, s. 17). Nacjonalizm dla Smitha to "ruch ideologiczny, mający na 
celu osiągnięcie i utrzymanie autonomii, jedności i tożsamości w imieniu zbiorowości, której niektórzy członkowie uważają, że tworzą rzeczywisty lub potencjalny naród" (Smith, 2009: 229). Tak rozumiane pojęcie może być podstawą dla ideologii głoszącej, że własny naród jest wartością najwyższą, której podporządkować się muszą prawa jednostek oraz innych narodów („nacjonalizm” - WSJP, b.d.).

Nacjonalizm [łac. natio 'naród'] to przekonanie, że naród jest najważniejszą formą uspołecznienia, a tożsamość narodowa najważniejszym składnikiem tożsamości jednostki, połączone z nakazem przedkładania solidarności narodowej nad wszelkie inne związki i zobowiązania oraz wszystkiego, co narodowe, nad to, co cudzoziemskie lub kosmopolityczne; ideologia polityczna, wg której podstawowym zadaniem państwa jest obrona interesów narodowych, a jego zasięg terytorialny winien odpowiadać obszarom zamieszkanym przez dany naród („, nacjonalizm" - Encyklopedia PWN, b.d.).

Zdaniem Smitha nacjonaliści dzielą świat na narody. Znają oni własny charakter, historię i przeznaczenie, a w narodzie widzą źródło władzy politycznej (Smith, 2009, s. 183). Rozbicie jedności chrześcijaństwa w późnym średniowieczu pozwoliło na powstanie w Europie typu tożsamości łączącego się z państwami monarchistycznymi. Trudno jednak uważać ten moment za powstanie nacjonalizmu. Stało się to w czasie radykalizacji reformacji w XVII wieku w takich państwach jak Anglia, Szkocja czy Niderlandy. Był to nacjonalizm oparty na przymierzu. Według Smitha to wyznacza centralny punkt socjologicznej historii kształtowania się narodów i nacjonalizmu. Autor dodaje, że „radykalny protestantyzm oparty na przymierzu dostarczył środków do dokonania przełomu ku nowożytnym narodom i nacjonalizmom" (Smith, 2009, s. 224).

Z kolei jak zauważa Michael Billig w swojej książce Banalny nacjonalizm, dostrzeganie nacjonalizmu dotyczy postaw występujących w ruchach skrajnych, oddalonych od nas samych. Prędzej przypisany on zostanie separatystom czy liderom organizacji skrajnie prawicowych niż przeciętnemu politykowi europejskiemu czy amerykańskiemu. Skutkiem tego jest lokowanie takiej postawy na obrzeżach tak politycznych, jak i terytorialnych (Billig, 2008, s. 30). Tak długo, jak właśnie tak wąsko będziemy dostrzegać nacjonalizm, tak długo może być on ignorowany i pomniejszany. Zdaniem Billiga może jednak dotyczy on nas bezpośrednio i to w o wiele większym stopniu, niż nam się wydaje.

Michael Billing krytykuje nauki polityczne, dostrzegające nacjonalizm jedynie poza państwami rozwiniętymi. Za niewystarczające uważa postrzeganie tego pojęcia przez Miroslava Hrocha, który definiuje nacjonalizm jako „walczący” rękami członków narodu "o terytorialną autonomię, jedność i niezależność". Hroch wyróżnia trzy stadia nacjonalizmu, który kończy się w momencie przekształcenia idei narodowej w państwo (Billig, 2008, s. 92). Pozostaje wątpliwość, czy po tym etapie nacjonalizm, który stworzył państwo, przechodzi płynnie w patriotyzm. Zdaniem Billiga, Michael Ignatieff w książce Blood and Belonging: Journeys Into the New Nationalism również popełnia błąd, ograniczając rolę nacjonalizmu, pomimo wprowadzenia pojęcia nacjonalizmu etnicznego oraz obywatelskiego - występującego w państwach rozwiniętych.

W raporcie, który tuż przed wybuchem II wojny światowej został opublikowany przez Królewski Instytut Spraw Międzynarodowych w Londynie, napisanym pod kierownictwem E. H. Carra (Burns, 1940), dokonano podziału na dwie drogi rozwojowe nacjonalizmu. Pierwszą była droga francuska i brytyjska - państwo wyprzedziło tu naród, a więc go stworzyło. W drugim wypadku, który według badaczy miał miejsce w Niemczech oraz w środkowej i wschodniej części kontynentu, najpierw powstał naród dążący do wytworzenia własnego państwa. Skutkiem tego jest postrzeganie narodu jako grupy zdefinio- 
wanej kulturowo, rasowo, czy etnicznie. Anthony D. Smith pisze, że naród to: „nazwana i samookreślona wspólnota ludzka, której członkowie kultywują wspólne mity, wspomnienia, symbole, wartości i tradycje (...) przestrzegają wspólnych zwyczajów i powszechnych praw". Tożsamość narodowa zaś to: „ciągła reprodukcja i reinterpretacja wzorca wartości, symboli, wspomnień, mitów i tradycji, które składają się na wyróżniającą spuściznę narodów, a także identyfikacja jednostek z tym wzorcem i spuścizną" (Smith, 2009, s. 36). Należy jednak rozróżnić pojęcia państwa i narodu. Państwo wyraża się w autonomicznych instytucjach na danym terytorium, natomiast naród określa pewien typ wspólnoty kulturowej i historycznej. Warto pamiętać, że pojęcia te mogą mieć ten sam zakres. Smith wskazuje na trudność rozróżniania w praktyce tych dwóch typów lojalności (Smith, 2009, s. 181). Zauważa on, że centralizacja państwa, przeniesienie religii do strefy prywatnej były podstawami do wykreowania narodów takich, jakie obecnie znamy i że ideologia narodu republikańsko-obywatelskiego wyłoniła się w końcu XVIII wieku (Smith, 2009, s. 180).

Zatrzymajmy się na kilku cechach polskiego nacjonalizmu, wyodrębnionych przeze mnie na podstawie programów ruchów nacjonalistycznych. Wielu osobom świat państw narodowych, świat granic, wydaje się odwieczny. Odwołania do zamierzchtej historii kraju, są często jednak (na wyrost) zrozumiałe dla społeczeństwa i dają często pożądany efekt spajania obywateli. Tendencja ta jest widoczna także w Polsce, chociażby koncepcja PRL-owskich ziem odzyskanych narzuca się tu w sposób naturalny. To właśnie państwa narodowe według Ernesta Gellnera (1991) powinny być łączone z nacjonalizmem. Wydarzenia takie jak Marsz Niepodległości, w którym w ostatnich latach uczestniczyło kilkadziesiąt tysięcy ludzi, uświadamiają nam, że odwoływanie się do patriotyzmu, tożsamości narodowej, czy też w końcu nacjonalizmu, ma w naszym kraju znaczną rzeszę młodych wyznawców. Nie można zapomnieć o inicjatywie pod nazwą Ruch Narodowy, powołanej przez największe organizacje narodowe w 2012 roku po Marszu Niepodległości.

$\mathrm{Na}$ internetowych stronach tej organizacji znajdziemy następującą deklarację ideową ( „Ruch Narodowy”, b.d.), w której organizacja odwołuje się do tożsamości - narodu, rodziny i osoby, oraz suwerenności - państwa i kultury. Fundamentami tożsamości są dla ruchu wartości takie jak chrześcijaństwo, rodzina, czy patriotyczne wychowanie, a naród winien być dumną i silną wspólnotą. Suwerenność rozumiana jest jako podstawowy instrument realizacji interesów narodowych, a myślenie elit nie może być zależne od obcych ośrodków. Ruchu Narodowy uważa, że główną siłą narodu powinna być świadomość i wola działania młodego pokolenia. Naród ma być jedynym gospodarzem w swoim państwie. Deklaracja organizacji kończy się następującym zdaniem: "Dlatego będziemy walczyć o Polskę dla Polaków - dumną, silną, dostatnią i bezpieczną". Taką ideologię popiera prawie 160 tys. użytkowników „Facebooka” („Ruch Narodowy”, b.d.). Z jednej strony, podkreślany jest patriotyzm, co nie wydaje się niczym złym. Z drugiej, gdy słyszymy hasto „Polska dla Polaków”, wzbudza to niepokój. Słowa te w prosty sposób kojarzą się z nacjonalizmem, a nawet szowinizmem. Organizacje te usiłują jednak ukryć w swych deklaracjach te cechy, przez które mogłyby zostać uznane za propagujące skrajne idee.

Młodzież Wszechpolska w swojej deklaracji ideowej mówi m.in. o tym, że „zamierza dokonać odnowy moralnej i narodowej młodego pokolenia, wypowiadając wojnę doktrynom głoszącym samowolę, liberalizm, toleracjonizm i relatywizm. Pragniemy wyprzeć z życia narodu podłość, fałsz i brud” („Deklaracja Ideowa”, b.d.).

By móc pragmatycznie porównać pojęcia patriotyzmu i nacjonalizmu, wyodrębniłem kilka cech programów nacjonalistycznych w Polsce. Są to: 
a. sprzeciw wobec polityki Unii Europejskiej

b. sprzeciw wobec komunizmu, syjonizmu, liberalizmu, faszyzmu i globalizacji

c. sprzeciw wobec napływu do Polski emigrantów i mieszaniu się kultur

d. obrona narodowej tożsamości, rodziny, wiernej wartościom chrześcijańskim

e. nierozróżnianie pojęć nacjonalizmu i patriotyzmu.

Ad a. W deklaracjach ideowych organizacji nie zauważa się jednoznacznego stosunku do Unii Europejskiej. Ruch Narodowy wspomina o chęci bronienia interesów Polski „wobec sił międzynarodowych i brukselskiej biurokracji. Poprzemy budowę Europy niepodległych narodów, opartej na dobrowolnej współpracy gospodarczej". Prezes Narodowego Odrodzenia Polski Adam Gmórczyk mówi o likwidacji Unii Europejskiej i idei „powrotu do zasady Europy Wolnych Narodów” („Naszym celem jest Europa Wolnych Narodów - wywiad prezesa NOP dla włoskiej AlP", 2013).

Ad b. Obóz Narodowo-Radykalny mówi o odrzuceniu demokracji liberalnej, jak również totalitaryzmów (komunizm, narodowy socjalizm, faszyzm), jako systemów obcych Polskiej tradycji. Za tym punktem kryje się również m.in. antysemityzm takich organizacji jak NOP, który wspomina o politycznym, ekonomicznym i terytorialnym imperializmie i syjonizmie. Potwierdza prawo każdego narodu do życia, bez - pośredniej lub bezpośredniej - ingerencji syjonizmu („Deklaracja Trzeciej Pozycji”, b.d.).

Ad c. Jest jawny i demonstrowany przez skrajne ugrupowania prawicowe tak, że cudzoziemcy ukrywają swój stosunek do Polaków. NOP twierdzi, że "grupy rasowe" nie powinny mieszkać w kraju kulturowo obcym.

Ad d. Przejawia się przez nietolerancję wobec innych religii niż katolicyzm. Widzą w nich zagrożenie dla tożsamości narodowej. Z tym zgadzają się bezsprzecznie organizacje skrajnie prawicowe.

Ad e. Nierozróżnianie pojęć patriotyzmu i nacjonalizmu należałoby tłumaczyć tym, że nacjonalizm traktowany jest kulturowo jako "zły patriotyzm”, patrz niżej o zespole "Horytnica”.

Wydaje się, że na podstawie wyodrębnionych wyżej cech zawartych w programach ruchów nacjonalistycznych można pragmatycznie wyznaczyć granicę między pojęciami nacjonalizmu i patriotyzmu, pomimo że ontologicznie jest to trudne i wręcz niemożliwe.

\section{POPKULTURA I POPNACJONALIZM}

Popkultura, czyli kultura popularna, masowa, ale też ludowa, lubiana, ciesząca się popularnością związana jest z ang. popular podobnie jak popnacjonalizm. W. J. Burszta odnosi pierwsze znaczenie „popnacjonalizmu” "do sfery przekonań i działań jednostek, wynikających z kulturowego bagażu ich doświadczeń". Jego zdaniem są one głęboko zakorzenione w pojęciu kultury narodowej, w systemie edukacji preferującej swojskość a nie obcość. Zdaniem autora, drugie znaczenie „popnacjonalizmu” jest ściśle związane z kulturą popularną (popkulturą). W tym przypadku mówienie o renesansie nacjonalizmu nie będzie z pewnością przesadą (Burszta, 2013b, s. 117). Kultura popularna zawłaszcza teren wcześniej zarezerwowany dla kultury wysokiej. Jak zauważa Julia Kristeva, zadeklarowana zwolenniczka kosmopolityzmu, ludzie sięgają do regresywnego jej zdaniem, wspólnego mianownika, jakim są korzenie i wiara odziedziczone po przodkach. Wynika to z potrzeby uporządkowania rzeczywistości, która nas otacza (Kristeva, 1993; Burszta, 2013a, s. 59). My sami jesteśmy czasem nieświadomymi uczestnikami plebiscytu "my to my", 
a "oni to oni" (Burszta, 2013b, s. 128). Silne przywiązanie do państwa i narodu w spoteczeństwie amerykańskim jest trudne do zrozumienia dla Europejczyków. Wynika ono z potrzeby manifestowania swojej przynależności narodowej, skupiania się, jak w przypadku Amerykanów w sporcie, na tych dyscyplinach sportowych, w których osiągają sukcesy. W pewnym stopniu jest to niedościgniony wzór utożsamiania się z własnym narodem, krajem. Popnacjonalizm występujący w polskiej muzyce chciałby osiągnąć taki, nawet tylko zbliżony efekt.

Sens zawodów sportowych spełnia się tylko w obecności widzów. Gra przy pustych trybunach jest dotkliwą karą nie tylko ze względów finansowych, ale i psychologicznych. Podobnie w przypadku występów muzyków w pustej sali. Twórcy muzyki popularnej widzą sens w swojej twórczości tylko poprzez dotarcie do jak największej ilości słuchaczy.

Popnacjonalizm w oczywisty sposób przejawia się w sporcie (Burszta, 2013a, 2013b). Wydaje się, że w mniejszym zakresie popnacjonalizm funkcjonuje również w muzyce popularnej, w tekstach polskich zespołów rockowych.

Zespoły należące do tego nurtu skupiają się na historii i wybranych wydarzeniach z przeszłości. Mówią o tym, jak istotna jest walka za ojczyznę, a także, co powinno być dla nas najważniejsze jako mieszkańców tego samego kraju. W tekstach tych artystów ich fani pokładają duże nadzieje na dotarcie wspólnych idei do szerokiej publiczności. Popnacjonalizm - w tym przypadku przejawiający się jako muzyka popularna, w szerszym jednak znaczeniu gatunku muzycznego niż pop - ewoluował od form skrajnych - z jawnymi nawoływaniami do nienawiści wobec wszystkich obcych ideowo - do łagodniejszych, pełnych powiązań, tekstów odwołujących się do historii. Warto podkreślić, że nie znajdziemy tam wątków antysemickich i rasistowskich. Wielokrotnie w tych tekstach można spotkać się z pojęciami: naród, barwy, kraj, honor, orzet. Przedstawiciele muzyki tożsamościowej nie chcą być banalnymi nacjonalistami. Uważają oni, że tematy, jakie poruszają, są bardzo ważne dla całego społeczeństwa i każdy z nas powinien to dostrzec. Poprzez złagodzenie swoich poglądów muzycy mają nadzieję trafić do jak największej liczby słuchaczy, stąd w ich twórczości odwołanie się do tradycji i historii narodu następuje w sposób akceptowalny i przystępny. Jednak ich twórczość wyrasta z podobnego nurtu popnacjonalizmu, a poglądy bardziej skrajne pojawiają się, chociaż nie wprost.

Jednym z takich zespołów jest „Horytnica”. W środowisku związanym z ruchami narodowymi zespół ten uważany jest za jeden z najważniejszych przedstawicieli rocka tożsamościowego. Na oficjalnym profilu na portalu Facebook („Horytnica”, b.d.-b) „Horytnica” określa się jako grający „patriotyczny rock metal”. W krótkiej charakterystyce, jaką można znaleźć na portalu internetowym „W Nas", autor tekstu zwraca uwagę, że „zespół nie ma szans na dostęp do szerszego grona odbiorców, pomimo tekstów o edukacyjnym charakterze, ponieważ media opanowane są przez polityków im nieżyczliwych i oligarchów. Zmianę może przynieść jedynie nowa władza” („Horytnica”, b.d.-c).

\section{CHARAKTERYSTYKA ZESPOLU "HORYTNICA"}

Muzyka rockowa w warstwie tekstowej, dzięki swemu powszechnemu charakterowi, jest sposobem zaprezentowania poglądów przez wielu muzyków. Dzięki popularności tego nurtu mają oni nadzieję trafić do jak największej grupy odbiorców. Muzyka rockowa jest obecna w popkulturze ponad pół wieku. Można wyróżnić trzy jej fazy: „naiwną" 
(1956-1965), „modernistyczno-awangardową" (1966-1980) i faze „postmodernistyczną”, którą Rychlewski w książce Rewolucja rocka nazywa "postrockową" (Rychlewski, 2011, s. 214). Chociaż rock wydaje się dinozaurem na tle obecnej popkultury, to nadal jest jednym z głównych nurtów w muzyce rozrywkowej. Oczywiście, jest bardzo zróżnicowany, zarówno w warstwie muzycznej, jak i tekstowej. Bez problemu odnajdziemy utwory, które znajdą uznanie osób o lewicowych, liberalnych, czy konserwatywnych poglądach. Muzyka ta od lat 60. XX wieku usiłowała opowiadać i odpowiadać na rzeczywistość. Ewolucję, jaką przeszła w swym słownym przekazie, można zaobserwować chociażby na przykładzie angielskiego zespołu „Pink Floyd”, dla którego z początku najważniejsza była muzyka, tekst zaś był raczej dodatkiem, natomiast w późniejszym okresie proporcje te zaczęły się odwracać. Słowo stało się ważne, a ówczesny lider, Roger Waters, miał nadzieję, że dzięki temu fani zespołu będą w stanie pojąć i zrozumieć otaczającą ich rzeczywistość tak, jak widzi ją on sam. To jego zamierzenie nie zawsze się udawało, czego przykładem może być irytacja podczas jednego z występów, gdy przerwał piosenkę, ponieważ uznał, że widzowie znajdujący się na wielkim stadionie nie słuchają tego, co śpiewa. Niezależnie od tego, czy kontakt ze słuchaczami jest udany, muzyka uważana jest przez wielu artystów za idealną platformę prowadzenia swych fanów przez świat. Tylko czy na pewno tego oczekują słuchacze?

Muzyka, która w swej twórczości odwołuje się do patriotyzmu, nacjonalizmu, czy nawet rasizmu, obecna jest na scenie muzycznej od końca lat 70. Momentem przełomowym była z pewnością twórczość angielskiego zespołu "Skrewdriver" oraz działalność jego lidera lana Donaldsona. Był on twórcą organizacji "Blood \& Honour" oraz organizatorem serii koncertów pod tytułem „Rock Against Communism” (RAC), w kontrze wobec akcji „Rock przeciw rasizmowi”.

Określenie „RAC" stosuje się wobec zespołów propagujących w swej twórczości hasła nacjonalistyczne, antykomunistyczne, rasowe.

Sama scena jest niejednorodna i można wyróżnić nurty działające równolegle, nie zawsze tożsame, ale łączone z "RAC". Niektórzy poprzez swoją twórczość wychodzą poza te ramy podziału i mogą być zaliczani równocześnie do różnych nurtów. Spotyka się zespoły rockowe, punkowe (określane jako Oi!), ale i takie, które grają ciężką muzykę metalową (np. black metal). Liczy się treść propagowanej ideologii. To ona łączy te różne nurty. Jak zauważa Marcin Rychlewski w książce Rewolucja rocka, "Dobrym przykładem jest rock lat siedemdziesiątych, wobec którego stosuje się wiele terminów o niejasnych zakresach znaczeniowych, w dodatku fundowanych na podstawie różnych kryteriów, jak rock progresywny, rock symfoniczny, symfoniczny pop, space rock, rock stadionowy, rock elektroniczny etc." [Rychlewski: 99]. Próbę podzielenia i uporządkowania zespołów tworzących w nurcie utożsamianym z "RAC" komplikuje wytworzenie się rocka tożsamościowego. Jest to nowe określenie, usiłujące w pewnym stopniu zastąpić "RAC” W popkulturze. Właśnie z rockiem tożsamościowym stara się być utożsamiana "Horytnica”.

"Horytnica" powstała w 2007 roku i dotąd wydała trzy albumy. Zespołem kierują Tomasz Beliński (śpiew i gitara) oraz Piotr Demkowski (gitara, gitara basowa). Ciekawe jest to, że na swoim profilu nie podają swych nazwisk. Zespół nie ma żadnych zdjęć, nie gra też koncertów.

W internecie można spotkać się z opiniami, że „taki przekaz ma szansę trafić do młodego pokolenia - pozbawianego stopniowo i w sposób wyrafinowany wiedzy historycznej”; "Jesteśmy świadkami narodzin nowego nurtu muzycznego - bo nie jest to muzyka ani typowo ideologiczna ani polityczna czy też religijna - to muzyka Historyczno-Tożsa- 
mościowa, której zadaniem jest umacnianie świadomości narodowej Polaków" (Forum "Zawsze po stronie Narodu", 2013).

Piosenka „Horytnicy” pt. „Nie musimy umierać” była nieformalnym hymnem Marszu Niepodległości w 2011 roku. Brak koncertów i nieafiszowanie się członków zespołu jest frapujące i to pomimo licznej rzeszy fanów w gronie narodowców (liczba wyświetleń poszczególnych utworów na "Youtube” dochodzi do 200 tys.). Jeden z nielicznych dostępnych wywiadów z członkami zespołu znajduje się na portalu „W Nas” i został przeprowadzony w 2013 roku przez Grzegorza Kasjaniuka. Czego możemy dowiedzieć się z niego o "Horytnicy"?

„Jesteśmy po prostu skromnymi osobami i nie zależy nam na gigantycznym rozgłosie. Pochodzimy z Galicji”; „Wiele polskich zespołów zagłębiało się w podobnej tematyce. Różnica polega na tym, że nam udało się dotrzeć do szerszego grona odbiorców, którym z tego miejsca gorąco dziękujemy za wsparcie. Być może "Horytnica” zawdzięcza taką a nie inną popularność rosnącemu apetytowi na patriotyzm". A czym jest patriotyzm? "(...) przede wszystkim to miłość do swojej ojczyzny i swojego narodu. Wszystkie poboczne aspekty takie, jak np. tradycja, przywiązanie czy historia zawierają się w powyższych słowach". Zespół nie chce konkretnie deklarować się politycznie. Duch Narodu widzi w Marszu Niepodległości: „Duchowi Narodu nie potrzeba ożywienia, lecz raczej otwarcia mu drogi do większej ilości rodaków".

W dyskusji pod wywiadem czytamy głównie pozytywne opinie. Chwalone są poruszane przez zespół wątki i patriotyczny przekaz. Można spotkać się nawet z opinią, że dzięki „Horytnicy" można uczyć historii Polski. W tekstach zespołu niejednokrotnie przywoływane są nasze barwy narodowe, orzet, honor, ojczyzna, walka, krew. Większość utworów odwołuje się do historii Polski, rzadziej można spotkać się z poglądami na temat obecnej sytuacji. „Horytnica” w swoim przekonaniu ma pielęgnować uczucia patriotyczne wśród swych stuchaczy.

$$
\begin{gathered}
\text { Kochana ma Polsko } \\
\text { Kochana ma Polsko, Ojczyzno jedyna, } \\
\text { Twe dumne barwy, biało-czerwone, } \\
\text { żyję dla Ciebie, Ty dla mnie zawsze będziesz trwać. }
\end{gathered}
$$

Mój hymn

Dlatego właśnie jestem tutaj

Tutaj chcę umrzeć i tu żyć

Czerpać natchnienie z mej ojczyzny

I ponad wszystko dumnym być

\section{Pamieć i duma}

Przed nami biały Orła znak, na marszach barwy naszych flag W pamięci naszej tamte dni, zwycięskich walk i polskiej krwi.

Teksty "Horytnicy" nie są zawoalowane, przekaz ma być prosty i zrozumiały dla każdego słuchacza. Muzyka w utworach zespołu jest nagrana tak, że nie dominuje nad tekstem utworu, i na nim powinien skupić się słuchacz. Wokalista stara się śpiewać wyraźnie, tak aby każde słowo mogło dotrzeć do słuchaczy. Nie zawsze się to jednak mu udaje. 
W utworze "Świty Zmartwychwstania” autor przekonuje, że lepiej jest dla Polski, gdy płonie, gdy walczy, niż gdyby zostało po niej tylko wspomnienie. Walka i pamięć o bohaterach przeszłości jest najważniejsza. Polacy muszą być wierni rodzinie, jednak gdy staną przed wyborem: życie albo męczeńska śmierć za ojczyznę, wybrać mogą tylko tę drugą możliwość. W utworze "Mały powstaniec" możemy usłyszeć historię, która, co ciekawe, idzie trochę pod prąd. W tekście wyrażono wątpliwość, czy ci młodzi chłopcy rozumieli, na co się porwali. Chyba tylko raz napotykamy tego typu refleksję. W pozostałych tekstach chwalone jest poświęcenie dla ojczyzny. Śmierć dla niej jest czymś pięknym.

\section{Krwią pisze do Ciebie list}

Dziś Matko Polsko przyjmij krew milionów Twoich dzieci

Z tej krwi powstanie nowy dzień na wiele tysiącleci

\section{Stary wiarus}

O życie Twoje wciąż się troskam, lecz dziś w potrzebie jest nasz kraj

Wydarzenia z przeszłości w omawianych tekstach zespołu mają nam pokazać, jak walka, czy poświęcenie jest ważne, aby naród przetrwał. To naród jest najważniejszy, nie jednostka. Pomimo że wspominanie historii Polski stanowi dużą część tekstów, to znaleźć możemy również odwołania do obecnej rzeczywistości. W takich utworach jak „Czas Wyboru" czy "I jak tu żyć" zespół wypowiada się o politykach - dążą oni do zniszczenia kraju i narodu. Czynią to dzięki chociażby otwarciu granic, przez co umożliwiają napływ obcych nacji i kultur. Kierują się jedynie pieniądzem i zyskiem. Obecni politycy nie są w stanie jednak tego zmienić, nieważne, z której partii pochodzą: „zmiana partii, te same twarze, okupują rząd i kraj".

W utworze „Śląski rycerz" możemy usłyszeć o radykalnych rozwiązaniach. "Lecz my nie wybaczymy zdrady, dla rządów hańby tylko sznur". Jeśli władza postępuje wbrew tradycji, nie pamięta o swojej historii, to nie może dalej rządzić. Zespół swój stosunek do lewicy przedstawia w utworze "Sierp i młot".

\section{Sierp i mtot}

Przyznajcie kim jesteście, że tak zależy na tym wam Abyśmy żyli w nędzy i wciąż niszczyli własny kraj Nie mogli krzyczeć głośno, o tym co każdy z nas już wie

I co dziś tak naprawdę dla tego kraju liczy się Walczycie z Polską z dumą w swym sercu A w swoich rękach każdego dnia niesiecie sierp i młot

Polacy muszą dalej walczyć o odzyskanie swojego kraju, tak jak robili to w przeszłości. Mimo polityki, która niszczy nasze społeczeństwo, jest jeszcze nadzieja. To właśnie ten utwór był nieoficjalnym hymnem Marszu Niepodległości w 2011 roku.

\section{Nie musimy umierać}

Już nie musimy umierać

A jednak w sercu blizna 
Zamiast patrzeć na swój kraj

Szydzicie z hasła "Ojczyzna”

Tracicie honor, język, mowę

Mówiąc, że to postępowe

Patriotyzm jest na dnie

Lecz armia wiary nadal trwa

Walcząca dumnie twarzą w twarz

Dzierżąca biały Orła znak

W repertuarze zespołu dwa utwory odbiegają tematem od pozostałych. Jednym z nich jest „Karczma pod Starym Dębem”, drugim „Uliczni wojownicy". W pewnym stopniu jest on pomostem, który łączy "Horytnicę" z bardziej radykalnymi zespołami nurtu "RAC".

\section{Uliczni wojownicy}

To moje miasto, to moja dzielnica

Mój dom i moja kamienica

Tu jest wesoło nocami

Kibole chodzą z bejsbolami

Gdy jeden dostanie z glana

To zaczyna się zabawa

Bo na jednych się nie kończy

Gdy agresor już się włączy

My idziemy na mecz

Zacznie się prawdziwa siecz

Już nadchodzi ta godzina

Ktoś dostanie znowu w ryja

Żaden frajer nie zapomni

Zawsze dumni, zawsze wolni

Pochwała dla takiej postawy, jaka wyłania się z utworu „Uliczni wojownicy”, nie powinna dziwić. Chociaż "Horytnica” stara się być zespołem przekazującym postawę patriotyczną, to jest wymieniana jednym tchem z takim zespołami "Gammadion" (który chociaż odszedł trochę od śpiewania o 14 słowach $^{1}$, to jednak jest bardziej radykalny) niż niedziałające już zespoły „Honor”, "Konkwista 88" czy "Legion”. W ich twórczości mowa nienawiści jest obecna w prawie każdym utworze. „Horytnica” poprzez złagodzenie swoich poglądów ma nadzieję trafić do największej liczby słuchaczy. Nie jest to już pochwała nacjonalizmu, który może znaleźć odbiorców w węższym gronie, tylko odwołanie się do tradycji i historii w sposób akceptowany i przystępny. Wyrasta jednak z podobnego nurtu "RAC" i popnacjonalizmu, a poglądy bardziej skrajne pojawiają się, jednak nie wprost. Zespół pragnie, aby usłyszeć ich „Głos Patriotów". Pytanie jednak, czy taki sposób propagowania idei trafi do nowych odbiorców - bo taki jest cel rocka tożsamościowego.

\section{…..}

Fourteen Words (ang. czternaście słów) to często używane przez neonazistów i białych rasistów, maskujące określenie zdań: We must secure the existence of our people and a future for White children (Musimy zagwarantować byt naszych ludzi i przyszłość dla Białych dzieci) („Fourteen Words”, b.d.). 
Rock tożsamościowy obecny jest w wielu krajach europejskich. Francuski nurt reprezentujący ten styl ("RIF" - Rock identitaire français) to prąd muzyczny opisywany jako patriotyczny. Wspierany jest przez różne organizacje związane z ruchem nacjonalistycznym we Francji. Pierwsi twórcy francuskiego rocka tożsamościowego pojawili się w drugiej połowie lat 90. Przedstawiali się jako "kontrkultura" czy "kultura rebelii”, przeciwna systemowi. Mieli nadzieję dotrzeć do szerszej publiczności niż nacjonalizm tradycyjny, w tym muzycy utożsamiani z "RAC”. Analiza Lucille Marbeau (2003) w L'Express pokazuje, że prawdziwym celem tego ruchu jest „przyciągnąć młodych ludzi w ramiona skrajnej prawicy". Marbeau wyjaśnia również, że tym, co charakteryzuje ten ruch nie jest rock, ale rasistowska ideologia, w której przez „tożsamość” rozumie się „białą rasę”. Z kolei francuski badacz kultury Nicolas Lebourg zauważa, że nazwa francuski rock tożsamościowy jest oszustwem, gdyż „RIF” obejmuje W rzeczywistości wszystkie gatunki muzyki. Dla niego tym, co charakteryzuje i wyróżnia "RIF" są cele polityczne, podobne jak w przypadku „RAC", jednak odżegnujące się od tego nurtu. Dzięki temu wydaje się możliwe "wprowadzanie nowych ludzi do idei nacjonalistycznych i być tym dla prawicy, czym zespół „Béruriers Noir” dla skrajnej lewicy” (Lebourg, 2010). Grupy, które należą do tego ruchu (m.in. „Vea Victis”, "Fraction”, „Île de France”), deklarują, że stoją w opozycji do imigracji. Są za prymatem własnego narodu, a przeciw globalizmowi i amerykanizacji. Lider "Vea Victis" o "RIF” wypowiadał się, że to bardziej stan ducha, sposób pojmowania świata niż odrębny styl muzyczny.

We Francji w 2005 roku sporządzono raport dla Centralnej Dyrekcji Wywiadu Ogólnego ${ }^{2}$ (DCRG - Central Directorate of General Intelligence). Autorzy opracowania zauważają, że skinheadzi, czy też neonaziści, są bardzo aktywni w ruchu rocka tożsamościowego. Mimo oskarżeń o rasizm czy nawoływanie do przemocy, żaden zespół czy tekst piosenki nie został dotychczas zaskarżony do sądu, w przeciwieństwie do twórców "RAC".

We Włoszech zespoły o podobnej tematyce wpisywane są w nurt muzyki alternatywnej (wł. Musica alternativa di destra), do którego zalicza się wszystkich twórców związanych z nurtem "RAC". Ważnym momentem w rozwoju muzyki alternatywnej we Włoszech były festiwale muzyczno-kulturalne organizowane przez Fronte della Gioventum, czyli młodzieżówkę Włoskiego Ruchu Społecznego 3 pod koniec lat 70. Przełom wieków to ponowny, dynamiczny rozwój rocka tożsamościowego (wł. rock identitario) oraz prawicowej muzyki "Oi!" Ważnymi przedstawicielami tej sceny są zespoły takie jak „Amici del Vento" czy "Compagnia dell'Anello" („Włoska prawicowa muzyka alternatywna”, b.d.; "Lorien - Archivio Storico della Musica Alternativa Italiana", b.d.).

\section{WNIOSKI}

Trudne, wręcz niemożliwe, jest dokładne ustalenie granic między patriotyzmem i nacjonalizmem w planie ontologicznym. Ciekawie różnicę pomiędzy patriotyzmem a nacjonalizmem zauważył Charles de Gaulle, według którego „Patriotyzm jest wtedy, gdy na pierwszym miejscu jest miłość do własnego narodu; nacjonalizm wtedy, gdy na pierwszym miejscu jest nienawiść do innych narodów niż własny."Pewne jest, że jakikolwiek

2 Źródło: http://www.cncdh.fr/IMG/pdf/Internet_raciste_en_langue_francaise.pdf

3 Włoski Ruch Społeczny lub Włoski Ruch Socjalny (wł. Movimento Sociale Italiano, MSI) - włoska prawicowa postfaszystowska partia polityczna, działająca w latach 1946-1995, pierwotnie neofaszystowska, stopniowo ewoluująca w kierunku narodowym i konserwatywnym („Włoski Ruch Społeczny”, b.d.). 
konflikt, zwłaszcza konflikt wojenny, przekształca patriotyzm w etnonacjonalizm. Na gruncie kulturowym prawdziwe konflikty i walka między "naszymi” i "obcymi" ujawniają powszechne już zjawisko - popnacjonalizmu w dziedzinie sportu.

Rock tożsamościowy wywodzący się z "RAC”, w tym "Horytnica”, jest stosunkowo nowym i węższym od popnacjonalizmu przejawianego $\mathrm{w}$ sporcie zjawiskiem popkultury. Nie jest to pełna i kompletna analogia do zjawisk sportowych, obejmujących szerokie masy odbiorców w różnym wieku.

Wyodrębnione przeze mnie cechy nacjonalizmu występują w tekstach opisanej w artykule "Horytnicy", jednak nie spotykamy tematów jawnie antysemickich. Opozycja "nasi - obcy" występuje jednak w tekstach piosenek takich, jak: "I jak tu żyć”, „Kraj zdradzony", "Nie musimy umierać”, „Pamięć i duma”, "Sierp i młot”, "Słowiańska armia pracy”, "Śląski rycerz". Ujawnia to nacjonalistyczne tendencje w tych utworach i zwłaszcza wyodrębnioną wyżej (cecha „e") - nacjonalizmu. Niektóre bowiem z zespołów rockowych chcą uchodzić za patriotyczne, a nie nacjonalistyczne. Co prawda, ontologicznie nie można rozgraniczyć patriotyzmu od nacjonalizmu, bo oba pojęcia odnoszą się do tego samego obiektu - ojczyzny i miłości do ojczyzny, ale można to zrobić pragmatycznie, w planie kulturowym.

Opisany w artykule kulturowy przejaw popnacjonalizmu ma mniejszą skalę niż w sporcie, jednak dotyczy postaw głównie ludzi młodych, stąd widać konieczność przyjrzenia się i dalszej, głębszej analizy tego zjawiska, zwłaszcza że jak dotąd temat ten nie był opracowywany przez kulturoznawców.

Ostatnie wydarzenia na Ukrainie, w tym negatywna rola Rosji, pokazują, jak aktualna jest tematyka patriotyzmu i nacjonalizmu, i jak świadome nierozgraniczanie tych pojęć może być wykorzystywane w sposób cyniczny przez państwa o tendencjach imperialnych, jaką jest Rosja. Putin opanował także grę w popnacjonalizm, walcząc o olimpiadę zimową i mistrzostwa świata w piłce nożnej, starając się zaprezentować Rosję jako kraj silny i nowoczesny. Czy to, co dzieje się za naszą wschodnią granicą, znajdzie odbicie w polskiej popkulturze?

\section{BIBLIOGRAFIA}

Agresywne antychińskie protesty w Wietnamie. Spalono zagraniczne fabryki. (2014, maj 14). Pobrano 7 kwietnia 2016, z http://wpolityce.pl/swiat/195438-agresywne-antychinskie-protesty-w-wietnamie-spalono-zagraniczne-fabryki

Billig, M. (2008). Banalny nacjonalizm. (M. Sekerdej, Tłum.). Kraków: Wydawnictwo Znak.

Burns, C. D. (1940). Review of Nationalism: A Report by a Study Group of Members of the Royal Institute of International Affairs. Ethics, 50(4), 470-472. http://dx.doi. org/10.1086/290183

Burszta, W. J. (2013a). Globalna ekumena popnacjonalizmu. Sprawy Narodowościowe, (42), 51-65.

Burszta, W. J. (2013b). Kotwice pewności wojny kulturowe z popnacjonalizmem w tle. Warszawa: Wydawnictwo Iskry.

Deklaracja Ideowa. (2013). Pobrano 4 stycznia 2014, z http://mw.org.pl/about/deklaracjaideowa/

Deklaracja Trzeciej Pozycji. (2014). Pobrano 4 stycznia 2014, z http://www.nop.org.pl/deklaracja-trzeciej-pozycji/ 
Forum internetowe „Zawsze po stronie Narodu”. (2013). Pobrano 2 listopada 2013, z http:// www.polskaofensywanarodowa.fora.pl/muzyka,38/muzyka-a-przeslanie,282.html

Fourteen Words. (2013). W Wikipedia, wolna encyklopedia. Pobrano z https://pl.wikipedia. org/w/index.php?title=Fourteen_Words\&oldid=45007781

Gellner, E. (1991). Narody i nacjonalizm. (T. Hołówka, Tłum.). Warszawa: Difin.

Horytnica - teksty piosenek, tłumaczenia piosenek, teledyski na Tekstowo.pl. (2013). Pobrano 29 grudnia 2013, z http://www.tekstowo.pl/piosenki_artysty, horytnica.html

Horytnica. (2013a). W Wikipedia, wolna encyklopedia. Pobrano 11 listopada 2013, z https:// pl.wikipedia.org/w/index.php?title=Horytnica\&oldid=45095484

Horytnica. (2013b). Pobrano 11 listopada 2013, z https://www.facebook.com/Horytnica? fref $=$ ts

Horytnica. (2013c). Pobrano 12 listopada 2013, z http://wnas.pl/artykul/842-historie-walkoo-wolnosc-horytnicy-posluchaj-niezwyklego-zespolu

Huu Ngoc. (2004). Wandering through Vietnamese culture. Hanoi: The Gioi Publishers.

Ignatieff, M. (1993). Blood \& belonging: Journeys into the new nationalism. London: BBC Books.

Koselleck, R. (2009). Dzieje pojęć: Studia z semantyki i pragmatyki języka społeczno-politycznego. (J. Merecki, W. Kunicki, Tłum.). Warszawa: Wydawnictwo Oficyna Naukowa.

Kristeva, J. (1993). Nations without nationalism. New York: Columbia University Press.

Kruczkowska, M. (2014, maj 13). W Wietnamie trwają antychińskie protesty. Powód? Chińska platforma wiertnicza umieszczona w pobliżu wybrzeży. Pobrano 7 kwietnia 2016, z http://wyborcza.pl/1,76842,15954824,W_Wietnamie_trwaja_antychinskie_protesty_Powod_Chinska.html\#ixzz3ByyLC3IU

Lebourg, N. (2010, styczeń 3). L'Histoire d'Unité Radicale. Pobrano z http://tempspresents.com/2010/01/03/nicolas-lebourg-histoire-unite-radicale/

Lorien - Archivio Storico della Musica Alternativa Italiana. (2014). Pobrano 7 kwietnia 2016, z http://www.Iorien.it/Pagine/MusiAlte.aspx

Marbeau, L. (2003, listopad 20). Rock de la haine. Pobrano 7 marca 2016, z http://www. lexpress.fr/informations/rock-de-la-haine_653842.html

Młodzież Wszechpolska. (2014). Pobrano 4 stycznia 2014, z http://mw.org.pl/

nacjonalizm - Encyklopedia PWN. (2014). Pobrano 4 stycznia 2014, z http://encyklopedia. pwn.pl/haslo/3945094/nacjonalizm.html

Narodowe Odrodzenie Polski. (2014). Pobrano 4 stycznia 2014, z http://www.nop.org.pl/

Naszym celem jest Europa Wolnych Narodów - wywiad prezesa NOP dla włoskiej AIP. (2013, kwiecień 17). Pobrano 7 kwiecień 2016, z http://www.nop.org.pl/2013/04/17/ naszym-celem-jest-europa-wolnych-narodow-wywiad-prezesa-nop-dla-wloskiej-aip/

Obóz Narodowo-Radykalny. (2014). Pobrano 4 stycznia 2014, z http://onr.com.pl/deklaracja.html

Ośrodek Rozwoju Edukacji. (2014, kwiecień 8), Pobrano 20 sierpnia 2014, z http://www. ore.edu.pl/

patriotyzm - Encyklopedia PWN. (2014). Pobrano 6 stycznia 2014, z http://encyklopedia. pwn.pl/haslo/3955049/patriotyzm.html

patriotyzm - Słownik SJP. (2014). Pobrano 6 stycznia 2014, z http://sjp.pl/patriotyzm

Rock Against Communism. (2014). W Wikipedia, wolna encyklopedia. Pobrano 4 stycznia 2014, z https://pl.wikipedia.org/w/index.php?title=Rock_Against_Communism\&oldid $=41460180$ 
Ruch Narodowy. (2014a). Pobrano 4 stycznia 2014, z http://ruchnarodowy.org/deklaracjaideowa

Ruch Narodowy. (2014b). Pobrano 4 stycznia 2014, z https://www.facebook.com/RuchNarodowy.net?fref $=$ ts

Rychlewski, M. (2011). Rewolucja rocka: Semiotyczne wymiary elektrycznej ekstazy. Gdańsk: Wydawnictwo Oficynka.

Smith, A. D. (2009). Kulturowe podstawy narodów. (W. Usakiewicz, Tłum.). Kraków: Wydawnictwo Uniwersytetu Jagiellońskiego

Szymczak, M. (2006). Modelowanie przy pomocy technologii ontologicznych (Praca magisterska). Uniwersytet im. Adama Mickiewicza, Wydział Matematyki i Informatyki, Poznań.

Waldenfels, B. (2009). Podstawowe motywy fenomenologii obcego, Warszawa: Oficyna Naukowa.

Włoska prawicowa muzyka alternatywna. (2014). W Wikipedia, wolna encyklopedia. Pobrano z https://pl.wikipedia.org/w/index.php?title=W\%C5\%82oska_prawicowa_muzyka_alternatywna\&oldid $=45411653$

Włoski Ruch Społeczny. (2014). W Wikipedia, wolna encyklopedia. Pobrano z https:// pl.wikipedia.org/w/index.php?title=W\%C5\%82oski_Ruch_Spo\% C5\%82eczny\&oldid $=39997747$

WSJP, nacjonalizm. (2014). Pobrano 6 stycznia 2014, z http://www.wsjp.pl/index.php?id_ hasla $=29370$

WSJP, patriotyzm. (2014). Pobrano 6 stycznia 2014, z http://www.wsjp.pl/index.php?id_ hasla $=29198$

Wywiad z zespołem Horytnica. (2014). Pobrano 30 grudnia 2013, z http://wnas.pl/artykuly/ 937-horytnica-duchowi-narodu-potrzeba-otwarcia-drogi-do-wiekszej-ilosci-rodakownasz-wywiad 